\title{
5 Marginal Justice: Coming to Terms with the Persecution of the 'Asocials'
}

Between 1933 and 1945, tens of thousands of men and women, boys and girls were being stigmatized and persecuted as so-called 'asocials'. Reliable numbers are still not available today (Hörath 2017, 11). In a speech in October 1943, Heinrich Himmler boasted about the number of 70,000 'asocials' and 'professional criminals' who had been detained in concentration camps until then (Hörath 2017, 319; WD 2016, 15). According to the Stiftung Brandenburgische Gedenkstätten, by 1945, more than 11,500 persons had been detained as 'asocials' or 'work-shy' in the concentration camp of Sachsenhausen, of whom 2,600 died there, and about 9,173 detained in Dachau (WD 2016, 16). In addition, a letter by Secretary of State Monika Grütters recently gives the number of 1,680 persons detained as 'asocials' in the concentration camp of Flossenbürg, of whom 204 died there, 250 persons in Bergen-Belsen, of whom at least 38 died there, and at least 1,196 persons in Neuengamme, of whom at least 230 did not survive the camp. As Anne Alex for the civil society initiative Arbeitskreis Marginalisierte - gestern und heute points out, these figures, however, do not include all those detained in workhouses, work colonies, 'beggar camps' (Bettlerlager), penitentiaries, youth camps or psychiatric institutions, nor those imprisoned by the police or condemned to forced labor for being or being deemed homeless, 'work-shy', a prostitute or a vagrant or otherwise 'asocial' (Alex 2015, 33; WD 2016, 15). How many of these people were killed in these institutions we do not know. It is important to see, however, that there was no clear-cut definition of being 'asocial' under Nazi rule and this category overlapped with others. Among those detained for being 'asocial' were many who were also marked as Gypsies, Jews, homosexuals, mentally ill or handicapped. These Nazi victims had little in common except that they did not live up to Nazi standards of being a productive, well-adjusted member of the German Volksgemeinschaft (German ethnic community). 
In the Federal Republic of Germany, those persecuted as 'asocials' under Nazi rule belong to the category of the so-called 'forgotten victims', a term coined in the 1980 s denoting those Nazi victims who were not entitled to reparations under the 1953 Federal Indemnification Act (Bundesentschädigungsgesetz, BEG). The 'forgotten victims', however, had never been 'forgotten', but they had been consciously excluded from post-war reparation policy. For (West) German reparation policy, it was not decisive what someone had suffered from the Nazi state but on what grounds. Persecution on the grounds that someone did not conform to Nazi standards of health, fitness, sexual way of life, productivity or usefulness does not count as typical Nazi injustice. In this chapter, I will argue that the so-called 'asocials' still have a particularly marginal status in historic justice policy in Germany today, even compared with other groups of 'forgotten victims'. Today, there are official state-sponsored memorials for homosexuals, Sinti and Roma, and victims of the 'euthanasia' programme in Berlin, and the Bundestag has formally condemned the Nazi sterilisation and 'euthanasia' programme as well as the persecution of homosexuals as Nazi injustice. The victims of the Nazi persecution of the 'asocials', by contrast, have not received an official apology nor is there a state-sponsored memorial or historical site to commemorate their suffering.

The chapter examines how official state policy in the Federal Republic has addressed the Nazi persecution of the 'asocials' and how it has taken measures of compensation and commemoration - or not. I argue that official German politics has largely failed to identify and confront the distinctive features of this type of persecution, namely that it targeted victims according to Nazi standards of productivity, economic usefulness and social conformism. It can thus be understood as a type of persecution based on a biopolitical rationality of enhancing the life forces of the collective, in this case the Volksgemeinschaft through promoting and fostering the orderly, useful and productive lives and eliminating the useless, unproductive, or no more productive ones. In effect, the Federal Republic has declared some motivations behind the Nazi crimes to be incompatible with its own normative foundations - and others not. The motivation of disciplining and reducing the number of those found unwilling to live an orderly, useful, productive life was not among the incompatible ones, it was not one that constituted a severe historic injustice and thus required reparations.

This chapter takes the Bundestag to be a key site and a key actor in the politics of historic justice in the Federal Republic of Germany, being the only federal constitutional body directly elected by the people. It is not only the 
body that can adopt or reject legal reparation schemes or summarily invalidate Nazi court rulings, but it can also condemn Nazi crimes and issue an official apology in the name of the people. Thus, the Bundestag has the power to actually do historic justice - or not. Therefore, I will focus on its activities concerning the persecution of the 'asocials'. ${ }^{1}$

The chapter is organized as follows. First, I suggest a performatist perspective on historic justice, asking what policy-makers actually do when they 'do justice' to victims of state wrongdoing in the past, for instance in the form of reparations schemes, apologies or commemoration practices. From this perspective, I argue, policies of historic justice are performative acts that inevitably link past, present and future in specific ways. Second, I briefly refer to the historical background to point out which infringements we are talking about when we speak of the persecution of the 'asocials'. The third section outlines the construction of the West German reparation scheme and explains in which sense the 'asocials' have been excluded here. Fourth, I examine the activities in and by the Bundestag of coming to terms with the persecution of the 'asocials', and the responses by the government pertaining to this. The chapter concludes that historic justice to the victims of the Nazi persecution of the 'asocials' has remained marginal in German politics. There has been no official act neither by the Bundestag nor by the Federal Government of specifying what exactly had been wrong about the persecution of the 'asocials' and what must, consequently, not happen again. Concerning this type of Nazi injustice, the Federal Republic has not performed a clear-cut break with the past.

I will use the phrase 'persecution of the asocials' although it is problematic on at least two counts. First, the term 'persecution' (Verfolgung) in German is mostly used to denote acts of mass violence committed or condoned by the state against religious, ethnic or political minorities. In this case, however, there was no group, whether religious, ethnic or political. Second, the use of the term 'asocials' means adopting the Nazi term. It refers to those prisoners in the camps marked by a black triangle; it is this triangle and the prac-

Sources are draft laws, parliamentary motions, parliamentary hearings, plenary debates, questions to the government in writing or questions to be discussed at a plenary session, government responses to these, and information provided to the Bundestag by the government. The documents are accessible through the Bundestag's electronic archives at http://pdok.bundestag.de/. Interestingly, a search for 'Asozialenverfolgung' yielded no results, whereas a search for 'Homosexuellenverfolgung' yielded 28 results (on 12 June 2017). 
tices that brought them there that together constitute the category of 'asocial', nothing else. I will therefore use the phrase 'persecution of the asocials' as shorthand for the Nazi practices of stigmatizing, deporting or detaining people in penitentiaries, workhouses or concentration camps and eventually killing them on the grounds that they were categorized as homeless or workshy, vagrants, beggars or prostitutes, or otherwise not conforming to Nazi standards of being a valuable member of the Volksgemeinschaft.

\subsection{Model Germany?}

The Federal Republic has often been lauded as the model case for 'coming to terms with the past' (Wolfrum 2009). For Timothy Garton Ash, 'past-beating' has turned into a veritable industry since 1989 and Germany into its worldwide leader (Garton Ash 2002, 32). Post-war Germany, it is often said, has confronted its Nazi past in ways that could serve as a model for other countries that have also committed large-scale human rights violations in the past (Buruma 1994; Cunningham 2004). In this vein, the German government has long lauded itself for its exemplary reparation policy: "All in all, the Wiedergutmachung can be considered a unique historical achievement that has received recognition from national and international organisations of Nazi victims, too." (BT Drs. 10/6287 1986, 11)

However, it is also true that German politics of Aufarbeitung und Wiedergutmachung have for a long time excluded many groups of Nazi victims for whom the term 'forgotten victims' came up in the early 1980s, referring to those who had suffered from systematic Nazi persecution but were not entitled to reparations under the BEG. This applies to coercive laborers, Roma and Sinti, homosexuals, those who had been coercively sterilized and those who were killed in the course of the so-called 'euthanasia' programme. The 'asocials' have remained among the most 'forgotten' among the 'forgotten victims'. While victims of 'euthanasia', coercive sterilisation and the persecution of homosexuals have received an official apology from the German government by, there have been no official acts of apology or commemoration for those who had been stigmatized, deported, imprisoned, detained in workhouses or concentration camps, or ultimately killed, for being allegedly work-shy, homeless, beggars, 
prostitutes or simply deemed 'asocial'. ${ }^{2}$ In more recent years, initiatives of commemorating these Nazi victims have mushroomed in Germany, but, except for some isolated efforts by the faction of the Left in parliament, they all originate in civil society, not in the Bundestag or other government bodies. In short, this type of persecution still figures marginally within German politics of the past and the logic that underlined it has scarcely been addressed by official politics.

\subsection{Doing Justice - or not. The Performative Politics of Historic Justice}

In German memory discourse, people who suffered from social rather than racial or political persecution are often addressed by the sociological term gesellschaftliche Randgruppen, marginal groups in English (e.g. Tümmers 2009). However, the discourse of Randgruppen is problematic here since it implies an ontological primacy of the target group; it implies that the existence of these 'groups' precedes the practices of stigmatizing and persecution such as rounding up, institutionalizing, detaining, imprisoning and killing. However, it is actually through these practices that the target 'group' has been constituted in the first place. No such 'group' existed until state actors began to distinguish between normal and abnormal, appropriate and deviant, adjusted and maladjusted, healthy and pathological, productive and unproductive, superior and inferior, valuable and worthless categories of people. In the context of reparation policies, the concept of Randgruppen obscures the question when, how and by whom certain categories were constructed for purposes of persecution and how these categories were still effective in reparation policies after 1945. I will not so much seek to explain why the 'asocials' have been excluded from reparation and commemoration policies, but explicate what this means. The focus is on what policy-makers do when they adopt or reject policies of historic justice. By policies of historic justice, I mean policies that self-critically address the nation's own past. Policies of historic justice in this sense may comprise political reparation programmes, official apologies, official commemoration days, state-sponsored memorials, commissions 
of inquiry or research programmes. Thus, policies of historic justice, as Regula Ludi (2005) states, inevitably make a set of performative distinctions: between legitimate claims for reparations and illegitimate ones, 'deserving' victims and 'undeserving' ones, condemnable abuse and justifiable acts of state power, things to commemorate and things to forget. Building on this, I suggest that policies of historic justice should be approached as performative acts in the way that theorists of apology understand apologies as performative acts (Lazare 2004; Tavuchis 1991). In this perspective, certain elements are required to make an apology: identifying the offence, the offended and the offender, taking responsibility for the offence and acknowledging the suffering it caused. Through offering an apology, offenders acknowledge that they have violated a fundamental moral or legal norm or principle, or a previous social contract with the offended. Thereby, the offender simultaneously confirms the validity of these norms, principles, contracts or promises and explicitly or implicitly promises not to violate them again. In the case of public apologies, it is the state who takes responsibility for the offence. In this case, it is critical that the person or body who speaks on behalf of the state is constitutionally entitled to do so. In a parliamentary democracy like the Federal Republic, this would certainly be the parliament, elected by the people, or possibly the chancellor, elected by the parliament.

In order to constitute proper acts of historic justice, policy measures such as reparation schemes or commemoration days have to fulfil the same requirements as public apologies, meaning they have to name the offence, the offended and the offender. In common with public apologies, policies of historic justice are performative acts through which actors make factual statements about what happened, issue a moral verdict, determine that wrongdoing has taken place, accept state responsibility for this wrongdoing, specify what was wrong about it and which norms or principles had been violated, confirm the enduring validity of these norms and principles and postulate that they are fundamental for the present political order, make a commitment to these norms and principles, offer means of making amends and promise non-repetition. Conversely, when governments decide not to condemn a certain course of state activity in the past and not to acknowledge that severe wrongdoing has taken place, they indirectly postulate that this course of action is not at odds with the present political order. Hence, policies of historic justice do not just struggle with 'the past' but at the same time they negotiate fundamental legal norms and principles and the nation's political imaginary in the present. They do all this simultaneously, within the same performative 
act. Thus, there is no intrinsic logic nor any quality to past atrocities that determines whether, when and to what extent governments take measures of making amends - or not; since what counts as condemnable abuse and what counts as a justifiable act of state power is a matter of moral and political judgement and political contestation (Sandner 2001; Teitel 2000; Wahl 2012). In a parliamentary democracy such as the Federal Republic, the parliament is both a key site where these contestations take place and a key actor that participates in them. Moreover, being entitled to make binding decisions about the fundamental norms and principles of the polity, the parliament has the highest authority to judge state actions in the past in light of present norms and principles and to make binding commitments with respect to the future. Parliamentary debates and decisions thus do not just reflect different views and judgements existing out there, but actually perform and enact binding judgements and commitments.

With regard to the persecution of the 'asocials' under Nazi rule, policies of historic justice have largely been incomplete or abortive. The Federal Republic has failed to issue any declaration that names the offence, the offended and the offenders and to take responsibility for the offences. Thus, it has not distanced itself from the logic that underlay the persecution of the 'asocials'; it has not condemned state violence against people on the grounds that they were being deemed work-shy, useless, homeless or otherwise maladjusted to norms and standards of productivity and economic usefulness. It has not declared such violations to be incompatible with its fundamental moral and legal order.

\subsection{The Nazi Persecution of the 'Asocials'}

Marginalization, discrimination and stigmatization of people for being deemed 'asocial' did not start in 1933, nor did this come to a close in 1945. Begging and vagrancy already constituted a criminal offence under the 1871 Imperial Criminal Code (Reichsstrafgesetzbuch, RStGB) and could be punished with imprisonment of up to six weeks ( $\$ 361 \mathrm{RStGB}$ ) or detention in a workhouse of up to two years ( $\$ 362$ RStGB) (Ayaß 1995, 44). However, the use of workhouses had nearly come to a halt at the end of the Weimar Republic.

After 1933, the police made excessive use of $\$ \$ 361$ and 362 RStGB and in the fall of 1933, big raids against homeless people, beggars and vagrants were already taking place and many thousands of people, according to Wolfgang 
Ayaß at least 10,000 people, were sent to workhouses or concentration camps (Ayaß 1995, 23ff.; 41). Most of them were set free again after six weeks. The situation worsened with the 'Law against Dangerous Habitual Criminals', which came into force in January 1934 and allowed for indefinite detention in a workhouse. To the present day, we have no reliable numbers about how many people were held in workhouses, work camps or so-called Bewahrungsanstalten between 1933 and 1945 (WD 2016, 15). From 1934 to the end of 1940, 7,956 persons were sentenced to workhouse detainment on the basis of $\$ 42 \mathrm{~d}$ of the 1934 law, according to official statistics (Ayaß 1988, 27).

Many inmates were imprisoned in workhouses for many years and many were sent to concentration camps over the following years. Since 1934, many municipalities also established coercive work camps (Lager der geschlossenen Fürsorge or Arbeitszwanglager) in addition to workhouses (Ayaß 2005). Furthermore, inmates of workhouses or work camps were systematically targeted for forced sterilization (Ayaß 1995, 47). In 1937, the Decree on Crime Prevention of 14 December 1937 authorized the police to circumvent the courts and imprison so-called 'asocials' 'preventively' in a concentration camp. The decree provided the pretext for major police roundups. It defined 'asocials' as persons who "without being a professional or habitual criminal endanger the public through their asocial behavior" (Decree quoted in Ayaß 1995, 139; 1998, document no. 50). In April 1938, executive guidelines for the decree declared: "Asocial is he who demonstrates through his anti-social, however not criminal behavior that he is not willing to adapt to the community." (Ayaß 1998, 142ff.)

The guidelines listed beggars, vagrants, prostitutes, alcoholics, the homeless, the work-shy, persons with a venereal disease or persons who did not pay alimonies, although this list was not supposed to be exhaustive. Many of the targeted were poor, but there was no 'social group' prior to the persecution; the group was constituted by the label imposed on people, through raids, imprisonment, detention, harassment and stigmatization, and eventually the black triangle attached to them in the camps. Based on the decree on 'crime prevention', the Gestapo and Criminal Police arrested more than 10,000 mostly male persons in April and June 1938 and sent them to concentration camps. The operation is nowadays known as Aktion 'Arbeitsscheu Reich'. It was mainly geared at adult males whose ability to work was exploited in the camps, among them many Sinti, Roma and Jews.

Women were targeted as 'asocials' too. According to Christa Schikorra, one in four who were deported to the women's concentration camp Ravensbrück between early 1939 and early 1940 were categorized as 'asocial' (Schiko- 
rra 2005). In total, approximately 120,000 women were imprisoned in Ravensbrück from 1939 to 1945, many for reasons of alleged prostitution, some for adultery in wartime (Kriegsehebruch), some for petty crime, some after having served a prison sentence for abortion. An estimated 25 percent of the women detainees categorized as 'asocials' had previously been detained in residential care institutions for youth (Schikorra 2005, 110). Younger girls were also imprisoned in a special concentration camp for girls and young women, the Uckermark concentration camp. Between 1942 and 1945, some 1,200 girls and young women between 14 and 21 years old and some boys were incarcerated here, among them many girls classified as 'hopeless cases' by Nazi welfare institutions. Girls could be classified as 'asocial' for all sorts of reasons, such as running away from welfare institutions or 'sexual depravation' (sexuelle Verwahrlosung), a term that could mean anything from having contact with Jews or foreign workers to promiscuity or in any other way departing from sexual norms of female behavior. Sexual depravation was a term uniquely used to categorize women (Initiative Uckermark 2009, 5). Boys and young men who had previously been detained in parallel institutions for male youth were sent to the youth concentration camp Moringen. A decree issued by Himmler in April 1944 declared that the purpose of the youth concentration camps was to:

...foster those who are still capable of adapting to the community so that they can fill in their place within the ethnic community (Volksgemeinschaft) and to detain those who are not amenable to education until their final detainment (in therapeutic institutions and institutions of care (Heil-und Pflegeanstalten), custody institutions, concentration camps), allowing for the use of their labor. (Himmler quoted in Ayaß 1998, 30)

'Healing and care institutions' (Heil-und Pflegeanstalten) was of course code for the institutions that systematically killed mentally ill or disabled people. The persecution of those stigmatized as 'asocials' thus merges into the elimination of the mentally ill and disabled and we see once again the biopolitical coupling of promoting productive lives and eliminating unproductive ones, with both strategies being directed at enhancing the strength and fitness of the collective body. We have to assume, says Martin Guse (2005), that one in ten inmates of the Moringen youth concentration camp did not survive.

In the Federal Republic, begging, vagrancy and prostitution continued to form a criminal offence until the major Criminal Code revision in the 1970s. Even workhouses continued to exist into the late 1960s (Ayaß 1995, 210). While people deemed to be 'asocial' were no longer sent to concentration camps, the 
institutions of the Federal Republic did not officially condemn these practices either. Claims for reparations were constantly rejected, even if someone had been detained in a workhouse for many years or imprisoned in a concentration camp. Such acts did not constitute 'typical Nazi injustice' for the authorities and the courts.

\subsection{Meaningful Work and Orderly Life}

In the early 1950s, the question of continuity and discontinuity came up in the Bundestag when the faction of the Zentrum launched an effort to introduce a new Custody Law (Bewahrungsgesetz) that was supposed to allow the detention of 'the mentally and morally weak' in closed institutions. In June 1951, the faction of the Catholic Zentrum party sub-mitted a proposal for a draft law to the Bundestag (BT Drs. 1/2366 1951). It stipulated that the purpose of detention (Bewahrung) was to protect the individual from deterioration (Verwahrlosung) and get him or her accustomed to meaningful work and an orderly life (BT Drs. 1/2366 1951, 1). The target group was constructed as individuals of full age who are deteriorating or at risk of deteriorating owing to a pathological or extreme mental or moral weakness or to a bluntness of moral sentiment (BT Drs. 1/2366 1951, 2). The law would have allowed the institutionalization of these people on either a temporary or permanent basis. During the pertaining parliamentary debate, MdB Helene Wessel presented the rationale for such a measure, namely that there were people who were mentally or emotionally 'abnormal' and therefore incapable of adjusting to society (BT PLP 1/163 1951, 6606B). True, Wessel conceded, the Nazi state had misused the restriction of personal freedom, but in her opinion that did not disqualify the new Custody Law (BT PLP 1/163 1951, 6606C). In other words, what the Nazi state had done to those categorized as 'asocial' in her view did not constitute a state crime but, in principle, an exercise of ordinary statecraft. Violating a person's right to personal freedom seemed acceptable when the person was incapable of adjusting to 'meaningful work and an orderly life' in society, in short of being a useful, productive member of the collective.

Others cautioned that the concept of deterioration was ill-defined and thus prone to misuse (BT PLP 1/163 1951, 6610D) and that 'we in Germany' have a special duty to prevent such misuse in order to overcome the 'bad inheritance' of the past. The sharpest criticism was brought forward by a Communist $\mathrm{MdB}$, Mrs Thiele, who referred to one million young people being unemployed 
at the time of the debate. Instead of enacting a law that would amount to bringing back Schutzhaft (a euphemistic Nazi term for detaining people without judicial decision or control), the state should take measures against mass unemployment and social distress (BT PLP 1/163 1951, 6612A-D). The proposal for a new custody law was eventually defeated in parliament. Yet, another incident shows that the spirit behind it was still alive a few years later. In 1962, when the Federal Social Benefits Act (Bundessozialhilfegesetz) was enacted, included the so-called custody provisions (Bewahrungsregeln) that would allow the authorities to institutionalize people in a workhouse "who, despite being repeatedly ordered, persistently refuse to take up acceptable work" (quoted in Stegemann 2013, 18). The provision, however, was eventually invalidated by the Constitutional Court in 1967.

Both incidents show that the idea of denying personal rights and freedoms to people for not complying with social standards of economic usefulness, productivity and an 'orderly life' was not out of the question for the Federal Republic.

\subsection{Excluded Victims}

There can be no dispute that the Nazi persecution of 'asocials' amounted to massive, systematic and severe human rights violations committed by the state. Yet, in common with the institutional killings, coercive sterilization and the persecution of homosexuals, it did not meet the definition of Nazi persecution as stipulated by the 1953 Federal Indemnification Act. The Act established a right to reparations for victims of Nazi persecution, subject to very restrictive residency requirements. The Act defines who counts as a victim of Nazi persecution, namely he or she who has been persecuted "for racial, religious, and political reasons or because of the victim's world view" (BEG $\$ 1(1)$ ). Thus, it stipulates that persecution for these reasons - but not others - is a severe breach of fundamental moral norms and principles of the Federal Republic. Thereby, it confirms that persecution for reasons of an individual's race, religion, political views or world view is incompatible with the Republic's moral, legal and political order. Conversely, the Act also defines who is not a deserving victim, namely he or she who has actively contributed to bringing about the Nazi regime, or who after 1949 has "fought against the free democratic constitution of the Basic Law" (BEG \$6(1)2)). The latter was mostly applied to Communists. Fighting Communists, as per the underlying ratio- 
nale, forms a legitimate exercise of statecraft, hence the present state cannot condemn its predecessor for having done the same thing in the past. The Indemnification Act singles out certain logics of state action which it considers incompatible with the present political order, namely stigmatizing, violating and killing people for being a member of a racial, religious or political group (except for the Communists) or a group that shares a certain world view.

Thereby, the post-war reparation scheme effectively excluded the 'asocials' from reparations since they had not been persecuted for any of these reasons - $\mathrm{a}$ fate they shared with other victims of what I termed the injuries of normality. The post-war reparation scheme of the Federal Republic has been constructed upon two basic assumptions. First, what is decisive is not what someone had suffered and what the state had done, but for what reasons it had done so. Second, it assumes that the state has the duty to respect and protect the rights of ethnic, racial, religious or political minority groups. Those categorized as 'asocial', however, did not form a 'minority' group; people were marked by the Gestapo, the police or the local authorities as presenting a burden or a threat to the Volksgemeinschaft, not for belonging to a certain group. These practices of marking and persecution reinforced, radicalized and executed biopolitical norms and standards of conformity, usefulness and productivity, thus establishing a system of differential valuation of human lives. However, these norms and standards had not been created by the Nazis. They formed part of an overarching biopolitical rationality that both predated and outlasted the Nazi regime. The German reparation scheme, however, was restricted to 'typical Nazi injustice' and thus excluded state wrongdoing that cut across the temporal confines of the Nazi period. Thereby, by definition, it ruled out the possibility of the Federal Republic continuing certain practices of the Nazi state. Yet, this was the case insofar as stigmatization, detention in workhouses and imprisonment for being homeless continued after 1945.

In the 1980s, many participants in civil society and in the Bundestag began to struggle for a reparation scheme that would go beyond the confines of the Federal Indemnification Act. These struggles were supported by the Greens and the Social Democrats, who formed the parliamentary opposition in the Bundestag at the time. The Greens proposed a new law that would have established entitlements to reparations for everyone who had person-ally suffered from Nazi persecution in Germany or the territories occupied by Germany between 1933 and 1945, proposing a broad concept of persecution based on the infringements someone had suffered, not on the group that they belonged to (BT Drs. 11/141 1987). The Social Democrats in parliament preferred 
the model of a new foundation 'Reparations for Nazi Injustice', funded by the government and supposed to compensate persons who had suffered from Nazi crimes but had not received compensation so far (BT Drs. 11/223 1987). The majority in parliament, however, did not adopt these propositions but established a new hardship fund in 1988 for Nazi victims who were not eligible to reparations under BEG. The institution in charge for managing the hardship fund became the Federal Ministry of Finance, not an independent body. When the Bundestag, again, debated reparations for Nazi victims in June 1989, oppositional MdBs complained that only 1.6 million Deutschmarks out of the 47.2 million budgeted for that year had been spent (BT PLP 11/151 1989, 11340C). The main problem, MdB Antje Vollmer from the Green Party remarked, was "...that the responsibility was given to an authority whose very own interest is saving money and whose representatives now sit on the government bench" (BT PLP 11/151 1989, 11344B).

When the hardship fund was established, people who had been persecuted as 'asocials' could theoretically apply for a one-off payment of 5,000 Deutschmarks. Few, however, tried and even fewer succeeded. In the period to 31 December 2011, a total of 354 persons categorized as 'asocial', vagrants, unwilling to work or work-shy by the Nazis had applied for hardship compensation and only 222 were successful (BMF 2012, 33).

\subsection{Forgotten 'Forgotten Victims'?}

When in the 1980s the new discourse about the 'forgotten victims' came up, there was some reference to the persecution of the 'asocials'. On the whole, however, the topic remained marginal. Reviewing the history of this discourse and the politics of historic justice through the lenses of the 'asocials' results in drawing up a long list of omissions. Since the 1980 s the Bundestag was concerned with a series of initiatives to confront, commemorate, condemn and compensate Nazi crimes and those against the 'forgotten victims' in particular. One can look at these discourses from a semantic and an interlocutionary perspective, in terms of content or conversation. As regards content, we can inquire, first, whether political speech acts - draft laws, proposals, questions and inquiries sub-mitted to the government, governmental responses and reports, parliamentary debates, hearings or speeches dealing with Aufarbeitung und Wiedergutmachung - do mention this type of persecution at all. Second, whether they do so in a more nominal way by just listing it or in a more 
substantial way by specifying offences, offended and offenders, and third, whether and when we see initiatives addressing this particular type of persecution. From an interlocutionary perspective, the major question is whether policy-makers talked to people who had suffered from this type of persecution or just talked about them, that is, whether these Nazi victims were treated as active participants in political conversations or as passive beneficiaries of certain policies.

Let us begin with the latter. Survivors of the persecution of 'asocials' never entered the politics of historic justice as participants, neither individually nor collectively. When the Social Democrats in parliament submitted their initiative for a new foundation for compensating Nazi injustice in 1987, they named a number of victims' organizations supposed to be represented on the board of trustees. That foundation never came to be but it is worth noting that no association representing the 'asocial' Nazi victims was mentioned in this context (BT Drs. 11/223 1987). In June 1987, the Parliamentary Committee on Internal Affairs held an important public hearing on Wiedergutmachung und Entschädigung für nationalsozialistisches Unrecht in Bonn (Deutscher Bundestag 1987). It was the first public hearing where victims of Nazi persecution, including 'forgotten victims', could tell their story to members of the Bundestag. Two years later, when the Bundestag debated the allocation of resources for Nazi victims, $\mathrm{MdBs}$ recalled that the hearing and the testimonies had left a lasting impression on them. It was, as Antje Vollmer said, “...as if many became aware for the first time how many groups of Nazi victims were living without recognition and compensation in the Federal Republic and abroad. ... There have been tears at the hearing." (BT PLP 11/151 1989, 11344A)

Among the participants were representatives of Sinti and Roma, people who had been forcibly sterilized, surviving victims of the 'euthanasia' programme, homosexuals and forced laborers - but no representatives of 'asocials'. Only one participant, the historian Wolfgang Ayaß, represented the group. Arguably, there was no association of 'asocial' Nazi victims at that time. At least no association publicly complained that they had not been invited. Whatever the reason, the fact remains that those labelled 'asocial' by the Nazis had no voice in the politics of historical justice. In terms of content, the 'asocials' were absent for a long time too. When President Richard von Weizsäcker gave his celebrated speech on 8 May 1985 and, as first official representative of the Federal Republic, commemorated the 'forgotten victims' such as homosexuals and those who had been coercively sterilized or killed 
in mental institutions, he did not mention the persecution of the 'asocials' (Bundespräsidialamt 1985).

In the following years, a number of parliamentary initiatives were launched for a more comprehensive and inclusionary politics of Aufarbeitung und Wiedergutmachung. During the $10^{\text {th }}$ and $11^{\text {th }}$ Bundestag, the Greens launched a proposal for a draft law that would provide social benefits to all victims of Nazi persecution (BT Drs. 10/4040 1985), the Social Democrats proposed that the government submit a report on how to improve reparations for Nazi victims (BT Drs. 10/4638 1986), the Greens again proposed a draft law for adequate social benefits for all Nazi victims (BT Drs. 11/141 1987) in April 1987, the Social Democrats proposed a draft law for a foundation 'Reparations for Nazi Injustice' in May 1987 (BT Drs. 11/223 1987), the Committee on Internal Affairs submitted a report on a new hardship fund for the 'forgotten victims' in 1987 (BT Drs. 11/1392 1987) and in 1987 the Social Democrats proposed guidelines for allocating means to a more inclusive range of Nazi victims (BT Drs. 11/1413 1987). Of these motions and reports, two mention a range of 'forgotten victim' groups but not the 'asocials' (BT Drs. 10/4638 1986; BT Drs. 11/223 1987), three mention the 'asocials' or 'socially persecuted' amongst others, without, however, specifying the violations they had suffered (BT Drs. 10/4040 1985; BT Drs. 11/141 1987; BT Drs. 11/1413 1987) and the rest make no mention of specific groups.

The Social Democrats in parliament used the term socially persecuted (Sozialverfolgte), which at least hints at the specificity of this type of persecution. They did not say, however, what this means, who was afflicted or who the perpetrators were. More can be learned from the report provided by the government on the request of the Bundestag on Wiedergutmachung and reparations for Nazi injustice, and the situation of Roma and Sinti and related groups. The report names some of the offences and the offended, namely:

persons who were taken to a concentration camp or another prison site for reasons of 'security' without regular trial and without sentence or after having served their prison sentence. Such measures were directed, for instance, at poachers, sexual criminals, pimps, vagrants, drunks, work-shy, dangerous criminals, so-called asocials, persons failing to pay alimonies, psychopaths, mentally distorted, and prostitutes. Homosexuals were affected as well. (BT Drs. 10/6287 1986, 39)

The report devotes a few lines on the logic that had underlined these infringements: 
Against this group of people so-called preventive measures were taken as well during Nazi rule. These measures served to subject this group to regular work and at the same time to recruit workers who, due to the tense situation in the labor market, were in short supply. [...]. In 1938, two actions were taken against the so-called work-shy and those imprisoned in the course of these actions were taken to the concentration camp Buchenwald. According to the findings of the Institute for Contemporary History, however, we have to assume that the majority of these prisoners were released in 1939 in the context of an amnesty on the occasion of Hitler's birthday. (BT Drs. 10/6287 $1986,41)^{3}$

Hence, what we learn from the government report is that the Nazi state violated these persons' right to the due process of law. We learn little about the logic that drove these infringements other than, apparently, it having to do with a labor shortage at the time and the strategy of the state to recruit additional labor. In short, the report suggests, the Nazi state acted out of economic rationality. It does not become clear whether the government condemns this course of action, and if so, on what grounds.

The Greens in parliament discerned a different logic at work. In 1995, they launched an initiative to establish a new foundation for reparations for Nazi crimes (Entschädigung für NS-Unrecht) supposed to grant reparations to all victims of Nazi persecution, not just those listed by the Federal Indemnification Act:

The purpose of the foundation is that all persons who had been subject to Nazi persecution get acknowledged as victims of National Socialism and in principle received continuous material benefits as compensation. Nazi persecution is each measure of Nazi injustice against the life, body, health, freedom, professionalism or property. (BT Drs. 13/1193 1989, 1)

The key criteria to delineate legitimate from illegitimate reparation claims were supposed to be the acts of injustice as such, not the grounds on which they had been inflicted upon people. The proposal would have radically reorganized the West German reparation scheme. In the proposal, the Greens named as prospective beneficiaries inter alia "persons who on the grounds of upon Hitler's $50^{\text {th }}$ birthday (Ayaß 1988, 22). 
their way of living or living situation were treated as being parasitic to the community, according to Nazi ideology (e.g. 'gripers', 'work-shy', 'homeless') and harmed as such." (BT Drs. 13/1193 1989, 2)

Albeit briefly, the proposal thus addresses the specificity of this type of persecution and to some extent identifies a specific logic behind it, namely the logic of persecuting people for a way of life that, whether freely chosen or not, does not conform to Nazi ideology. Yet the Greens were a small minority faction in the Bundestag without a realistic chance of getting the proposal approved. Later, when they formed a coalition government with the Social Democrats in 1995-2005 and thus had a parliamentary majority, neither of them came back to their former proposals.

It was not until 2008 - the year of the Aktion's $70^{\text {th }}$ 'anniversary' and also the year of the financial crisis - when the Left inquired about commemorating the Aktion 'Arbeitsscheu Reich' of 1938 that a parliamentary action addressed the persecution of the 'asocials' separately, as a stand-alone topic. The Question explicitly linked the events of 1938 to the situation in 2008 and vice versa: "Since people who have been marked as 'asocial' are increasingly exposed to aggressive acts this type of anti-human hostility should have a place within the politics of reminding and commemoration." (BT Drs. 16/9405 2008, 2)

The list of questions submitted here refers inter alia to the number of 'asocials' sterilized, imprisoned, impaired, sentenced to death, executed, detained and/or killed in prisons, penitentiaries, concentration camps or medical institutions. It further inquired about the government's plans to obtain such data, about the amount of reparations paid so far, plans to examine the role of ministries, authorities and other parts of government in these violations (Aufarbeitung), and further plans, projects and activities to commemorate these crimes. Albeit briefly, the inquiry names the offence, the offended and the offender, namely the Sturmabteilung and the police. This was the first parliamentary or governmental action to do so.

The government's response mostly states that the government had no information concerning numbers of victims or offences, no intentions to obtain them, and no plans or intentions as regards commemoration. The only concrete data provided were data on hardship compensation payments. According to these, 163 'asocials', 17 persons who had refused work (Arbeitsverweigerer), 24 work-shy and one vagrant had received a one-off payment of $€ 2556.46$ up to that date (BT Drs. 16/9887 2008).

In 2010, the Left in parliament again submitted a question in writing to the government, inquiring about the site of the former concentration camp 
Uckermark for girls and young women categorized as 'asocial'. Most of them, the question holds, were detained because their behavior did not conform to the norms of Nazi society:

Changing the place of residence, periods without proof of employment, refusing service in the Bund Deutscher Mädel [League of Cerman Girls], or acquaintances with men who were stigmatized or discriminated against could lead to accusations of 'hanging around' or 'sexual depravation' and detainment in a concentration camp. (BT Drs. 17/1493 2010,1)

The question also names the ordeals and injustices the inmates suffered such as malnutrition and coercive labor for the company Siemens. When the Left inquired whether the government had any plans to develop a commemoration site devoted to this group of Nazi victims, the government responded that the authority in charge was not the Federal Government but the State of Brandenburg. On the question which memorials or commemoration sites existed that were particularly devoted to those who had been stigmatized and persecuted as 'asocials', the government responded: "On the federal level, no memorial sites or sites of commemoration are known that are particularly dedicated to the group of people Nazi victims persecuted as 'asocials'." (BT Drs. 17/1721 2010, 4)

These two interventions by the Left in parliament remained isolated over the following years. In sum, over the past decades, the German government has acknowledged for a fact that thousands or tens of thousands of men and women, girls and boys had been deprived of their freedom, health, dignity and/or life because the way they lived did not conform to Nazi norms of productivity or being adjusted to society. The government did not deny the factual truth of these violations. Nor did it deny that the state had been responsible. However, it did not view these violations as typical Nazi injustice and accordingly did not grant reparations under the Federal Indemnification Act. Nor did any German government or the Bundestag ever issue an official apology for these violations. Neither did the Federal Government ever set up a commission of inquiry into these aspects of the Nazi past, nor sponsor any specific commemoration practices such as developing and sustaining a memorial site. The Federal Republic never officially specified what, if anything, had been wrong about stigmatizing, detaining and persecuting people as 'asocials'. There is no official declaration that names offence, offended and offenders. In the absence of such a declaration, the Federal Republic has not drawn a line between the past and the present, it has not identified or condemned the 
logic that under-lined this type of persecution, it has not specified the moral or legal norms and principles that had been violated, and consequently it has not committed itself to these norms and principles in the present and has not promised non-repetition.

\subsection{Commemoration Beyond the State}

In recent years, an impressive number of civil society initiatives have struggled to commemorate the persecution of the 'asocials'. Today, many sites of former violence such as the site of the former youth concentration camps Uckermark and Moringen, as well as the site of a former workhouse called Rummelsburg (Irmer 2013; Irmer, Reischl et al. n.y.) in Berlin-Lichtenberg, have been turned into memorials by local civil society groups. They organize conferences, talks and workshops, discover and preserve memorial sites, and provide information and analyses in form of articles, books and websites. Through placing the persecution of the 'asocials' in the context of the economic crisis, social inequality, marginalization and exclusion, they articulate commemoration and social critique. They draw a continuum between past and present and problematize the injustices of the latter in light of the former. A very active group is the Arbeitskreis Marginalisierte - gestern und heute, a name that deliberately articulates the past with the present. In addition, in German the name signifies both 'working group on marginalized people' and 'working group of marginalized people'; hence, it addresses the marginalized both as subject matter and as active participants. The group makes it very clear that it seeks to expose and condemn the continuity of social marginalization before, during and after the Nazi era and this continuity, in their view, is at least partly due to capitalism. It is the marginalizing effects of capitalism that they seek to bring to the fore - a project not particularly supported by the government. Nevertheless, if the government were looking for interlocutors to talk to about commemorating the persecution of 'asocials', it could find them here. These activists self-identify as people affected by social marginalization, many of them know first-hand what it means to be poor, unemployed or homeless, and thus vulnerable to stigmatization, criminalization or violence, many of them have become experts on the persecution of 'asocials' under Nazi rule, and they have made it their cause to prevent similar things from happening again. 


\subsection{Conclusion}

Tens of thousands of men and women, boys and girls were stigmatized, deported, detained in penitentiaries, workhouses or concentration camps. Many were eventually killed on the grounds that the way they lived did not conform to Nazi norms and standards of being a productive, valuable, useful, welladjusted member of the Volksgemeinschaft. Like other 'forgotten victims' of Nazi crimes, they are still excluded from reparations under the Federal Indemnification Act since their suffering does not count as Nazi persecution in the sense of the law. Only a few hundred have received a small amount of hardship compensation payment. Unlike many other groups of 'forgotten victims', those categorized and persecuted as 'asocials' have not received an official apology, nor is there a state-sponsored memorial, museum, foundation or historical site to commemorate their suffering. In their case, there has been no declaration by the Bundestag or the Federal Government that names offence, offended and offender. Despite the fact that the infringements, the violence and the degradation they suffered have been acknowledged as a fact and mentioned as one type of persecution amongst others since the 1980s, until 2008 no parliamentary or governmental action referred to this type of persecution in particular. Those two initiatives in the Bundestag that finally did so, remained marginal themselves. From a pragmatist perspective, this means that the Federal Republic has failed to specify what exactly was wrong about these infringements, whether, why and in what way this was an abuse of state power and not the exercise of statecraft. In failing to do so, the Federal Republic has failed to distance itself from the biopolitical and productivist logic that underlay the persecution of the 'asocials'. The Federal Republic has condemned state violence against people on the grounds that they were homosexual, disabled or mentally ill, but not on the grounds that they were homeless, unemployed, poor or deemed to be work-shy, useless, or just mal-adjusted to norms and standards of productivity and economic usefulness. The state has avoided clarifying which ways of treating the socially marginalized are acceptable and which are not, thereby avoiding making a commitment on how to treat the socially marginalized. The state, therefore, has not declared violations on these grounds to be incompatible with its fundamental moral and legal order. In turn, this says something not only about the past but also about the present. 


\subsection{Addendum}

On February 13, 2020, at the beginning of the Corona crisis and largely unnoticed by the general public, the majority of the Bundestag adopted a declaration on the acknowledgement of 'Asocials' and 'Habitual Criminals' as victims of Nazi persecution. All MPs voted in favor of the declaration, except those from the right-wing extremist party Alternative for Germany who voted against. With this declaration, the Bundestag responded to the petition "Acknowledgement of 'Asocials' and 'Habitual Criminals' as Nazi Victims" that had been launched in April 2018. It received broad support from a number of parliamentarians, artists, scholars, and other figures from public life and was signed by over 21,000 people. It states that the Nazis persecuted, stigmatized, incarcerated and murdered homeless persons, beggars, alcoholics and migrant workers and "carried out a kind of socio-biological prevention of violence among those with criminal records" by detaining them in concentration camps after serving a prison sentence, on the assumption of the existence of criminal genes (BT Drs. 19/14342 2020, 2; 3). The fate of these victims, the Bundestag declared, has not yet been commemorated and this needed to change: "No one was rightly imprisoned, tortured or murdered in a concentration camp". (BT Drs.

19/14342 2020, 3) 
